\title{
IMPLEMENTASI KURIKULUM 2013 PADA BIDANG STUDI PENDIDIKAN AGAMA ISLAM KELAS XI SMK NEGERI 3 PAREPARE
}

\author{
Haizah \\ Guru SMKN 3 Parepare
}

\begin{abstract}
This paper aimed to empirically determine and describe: lesson planning in the 2013 curriculum, the implementation of the 2013 curriculum, learning assessment conducted by the class XI teacher of Pendidikan Agama Islam at SMK Negeri 3 Parepare. The method aiming at describing an existing phenomenon and its true condition by using observation techniques, interview, and studying documents. The data were then analyzed by following the steps of (1) data reduction; (2) data presentation; (3) the data conclusion and verification. The results of the study showed that to date SMK Negeri 3 is still applying 2013 curriculum as its reference for a learning process.

The implementation of the 2013 curriculum was determined by (1) lesson planning; (2) learning implementation; and (3) learning assessment. At the stage of lesson planning, teacher designs lesson plan which are then implemented in learning process by applying a scientific approach consisting of the following stages: (1) observing; (2) questioning; (3) collecting materials; (4) processing materials; and (5) communicating, which is then followed by administering authentic assessment on the learning in the forms of: (1) observation; (2) oral and written test; (3) self assessment; (4) peer-assessment; (5) journal; (6) performance assessment; and (7) portfolio assessment. Factors that support the implementation of the 2013 curriculum include (1) teacher; (2) learners; (3) infrastructure and facilities; and (4) environment. On the other hand, the hindering factors are (1) lack of learners' care with their lessons; (2) lack of teachers' understanding of 2013 curriculum due to minimum education and training.
\end{abstract}

Keywords: Implementation, Curriculum, Learning, PAI.

\begin{abstract}
ABSTRAK
Artikel ini bertujuan untuk mengetahui secara empirik dan dapat mendeskripsikan tentang: persiapan perencanaan, pembelajaran, pelaksanaan dan penilaian Kurikulum 2013 pembelajaran yang dilakukan oleh guru Pendidikan Agama Islam
\end{abstract}


kelas XI SMK Negeri 3 Parepare, pada implementasi Kurikulum 2013 di SMK Negeri 3 Parepare.

Metode yang digunakan dalam penelitian ini adalah metode kualitatif yang bertujuan untuk menggambarkan fenomena yang ada dan menggambarkan kondisi apa adanya dengan menggunakan teknik observasi, wawancara, dan studi dokumentasi. Selanjutnya data dianalisis dengan menggunakan teknik; (1) reduksi data; (2) penyajian data; dan (3) menyimpulkan dan verifikasi data.

Hasil penelitian ini menunjukkan bahwa, SMK Negeri 3 Parepare sampai sekarang ini tetap menggunakan Kurikulum 2013 sebagai acuan dalam proses pembelajaran. Implementasi Kurikulum 2013 ditentukan oleh: (1) perencanaan pembelajaran; (2) pelaksanaan pembelajaran dan (3) penilaian pembelajaran. Pada tahap perencanaan pembelajaran guru menyusun Rencana Pelaksanaan Pembelajaran (RPP) yang kemudian diimplementasikan dalam pelaksanaan pembelajaran dengan menggunakan pendekatan saintifik yang langkah-langkahnya adalah: (1) mengamati; (2) menanya; (3) mengumpulkan bahan; (4) mengolah bahan;dan (5) mengomunikasikan, kemudian selanjutnya melaksanakan penilaian auntentik dalam pembelajaran berupa: (1) penilaian pengamatan; (2) penilaian tes tertulis dan tes lisan; (3) penilaian diri; (4) penilaian antar teman; (5) penilaian jurnal; (6) penilaian kinerja; dan (7) penilaian portofolio. Faktor pendukung dalam implementasi Kurikulum 2013 adalah; (1) faktor guru; (2) faktor peserta didik; (3) faktor sarana dan prasarana; dan (4) faktor lingkungan. Sedangkan faktor penghambatnya adalah (1) sikap peserta didik yang kurang peduli terhadap pelajarannya; dan (2) kurangnya pemahaman guru terhadap Kurikulum 2013 akibat kurangnya pendidikan dan latihan.

Kata Kunci: Implementasi, Kurikulum, Pembelajaran, PAI

\section{PENDAHULUAN}

Implementasi kurikulum 2013 dilakukan oleh guru dalam bentuk penyusunan Rencana Pelaksanaan Pembelajara (RPP) berdasarkan Permendikbud No. 81a Tahun 2013 Lampiran IV Tentang Pedoman Umum Pembelajaran, ${ }^{1}$ kegiatan pembelajaran yang memberikan kesempatan kepada peserta didik untuk mengembangkan potensi mereka menjadi kemampuan yang semakin lama semakin meningkat dalam sikap, pengetahuan, dan keterampilan yang diperlukan dirinya untuk hidup dan untuk bermasyarakat, berbangsa, serta berkontribusi

\footnotetext{
${ }^{1}$ Kemendikbud. 2013. Permendikbud No. 81A Tahun 2013 tentang Implementasi Kurikulum 2013, h. 61.
} 
pada kesejahteraan hidup umat manusia, dan pengukuran hasil proses pembelajaran.

Kurikulum 2013 dikembangkan dua modus pembelajaran yaitu pembelajaran langsung dan pembelajaran tidak langsung. Pembelajaran langsung adalah pendidikan di mana peserta didik mengembangkan pengetahuan, kemampuan berpikir dan keterampilan psikomotorik melalui interaksi langsung dengan sumber belajar yang dirancang dalam silabus dan RPP berupa kegiatan-kegiatan pembelajaran. Pembelajaran langsung menghasilkan pengetahuan dan keterampilan langsung atau yang disebut dengan instructional effect. Pembelajaran tidak langsung adalah pendidikan yang terjadi selama pembelajaran langsung tetapi tidak dirancang dalam kegiatan khusus. Pembelajaran tidak langsung berkenaan dengan pengembangan nilai dan sikap.

Kurikulum 2013 disiapkan untuk mencetak generasi yang siap dalam menghadapi masa depan, oleh sebab itu Kurikulum 2013 disusun untuk mengantisipasi perkembangan masa depan. Titik beratnya, bertujuan untuk mendorong peserta didik agar mampu lebih baik dalam melakukan observasi, bertanya, bernalar, mencoba, dan mengomunikasikan (mempresentasikan) apa yang mereka peroleh atau mereka ketahui setelah menerima materi pembelajaran. Adapun objek yang menjadi pembelajaran dalam penataan dan penyempurnaan Kurikulum 2013, yaitu menekankan pada fenomena alam, sosial, seni, dan budaya. Melalui pendekatan itu diharapkan peserta didik memiliki kompetensi sikap, keterampilan, dan pengetahuan yang lebih baik. Mereka akan lebih kreatif, inovatif, dan lebih produktif.

Kurikulum memuat apa yang seharusnya diajarkan kepada peserta didik, sedangkan pembelajaran merupakan cara bagaimana apa yang diajarkan bisa dikuasai oleh peserta didik. Pelaksanaan pembelajaran didahului dengan persiapan Rencana Pelaksanaan Pembelajaran (RPP) yang dikembangkan oleh guru baik secara individual maupun kelompok yang mengacu pada silabus. Kegiatan pembelajaran dirancang untuk memberikan pengalaman belajar yang melibatkan proses mental dan fisik melalui interaksi antar peserta didik, peserta didik dengan guru, lingkungan, dan sumber belajar lainnya dalam rangka pencapaian Kompetensi Dasar (KD). Pengalaman belajar yang dimaksud dapat terwujud melalui pendekatan pembelajaran yang bervariasi dan berpusat pada peserta didik. Pendekatan yang digunakan pada implementasi Kurikulum 2013 adalah pendekatan ilmiah atau pendekatan saintifik (scientific approach). Setelah pelaksanaan proses pembelajaran guru dituntut untuk memberikan penilaian yang bersifat objektif. Penilaian yang digunakan dalam Kurikulum 2013 adalah penilaian otentik. 
SMK Negeri 3 Parepare merupakan salah satu dari 13 (tiga belas) SMK Negeri dan Swasta yang ada di Kota Parepare yang lebih dulu menerapkan Kurikulum 2013 sejak Tahun Pelajaran 2013-2014. Sebagai sekolah piloting dan sebagai salah satu pelaksana kurikulum 2013 dari 448.904 SMK di Indonesia, maka kurikulum SMK Negeri 3 Parepare Tahun Pelajaran 2013-2014 mencakup dua kurikulum, yaitu Kurikulum 2006 (KTSP) sebagai lanjutan untuk kelas XI dan XII serta kurikulum 2013 khusus untuk kelas X. dan Tahun Pelajaran 20142015 diterapkan di kelas X dan XI. Tahun 2016-2017 mencakup satu kurikulum untuk semua kelas X, XI dan XII.

Kurikulum di SMK Negeri 3 Parepare menjadi acuan bagi satuan pendidikan dalam melaksanakan pendidikan dan pembelajaran dengan mengedepankan prinsip pengembangan kurikulum dan karakteristik Kurikulum 2013 dengan penyesuaian terhadap pemanfaatan analisis kondisi riil SMK Negeri 3 Parepare dan analisis kondisi lingkungan sekolah. Kondisi riil SMK Negeri 3 Parepare yang berada di lingkungan penduduk yang sudah lebih maju dibanding dengan sebagian daerah lain di Parepare, maka pengembangan kurikulum juga harus disesuaiakan dengan kondisi tersebut.

SMK Negeri 3 Parepare memiliki fasiltas pembelajaran yang cukup memadai dengan rata-rata pendidikan guru-guru berkualifikasi sarjana dan magister. Guruguru SMK Negeri 3 Parepare, khususnya guru bidang studi PAI telah memiliki pengetahuan tentang keterampilan dasar mengajar dan pengetahuan tentang kurilum 2013.

Perubahan kurikulum yang dilakukan oleh pemerintah adalah dengan maksud untuk memperbaiki pendidikan nasional. Kurikulum 2013 diharapkan dapat memberi dampak yang cukup besar dalam kegiatan pembelajaran, khususnya di SMK Negeri 3 Parepare. Terkait dengan hal tersebut, maka penelitian ini mencoba menelaah tentang Implementasi Kurikulum 2013 pada Pembelajaran PAI di kelas XI SMK Negeri 3 Parepare tahun akademik 2016-2017

Tulisan ini bertujuan untuk mengetahui secara empirik dan dapat mendeskripsikan tentang perencanaan pembelajaran Kurikulum 2013 yang dilakukan oleh guru PAI kelas XI SMK Negeri 3 Parepare, pelaksanaan pembelajaran Kurikulum 2013 di bidang studi PAI di kelas XI SMK Negeri 3 Parepare; berdasarkan dan penilaian yang dilakukan oleh guru PAI di kelas XI SMK 3 Parepare berdasarkan karakteristik Kurikulum 2013. 


\section{PEMBAHASAN}

\section{Perencanaan Pembelajaran}

Terdapat perubahan mendasar dalam Kurikulum 2013, khususnya bidang pembelajaran PAI. Perubahan yang dimaksud terjadi pada paradigma penetapan satuan kebahasaan yang menjadi basis materi pembelajaran. Perubahan pada materi tersebut, membawa dampak pada perubahan metode pembelajaran. Adapun yang menjadi basis pembelajarannya adalah teks. Jadi, pembelajaran PAI dilaksanakan dengan mempertimbangkan konteks situasi pemakaian bahasa itu sendiri. Hal tersebut dilakukan dengan alasan, bahwa melalui teks kemampuan berpikir peserta didik dapat dikembangkan dan materi pembelajaran berupa teks lebih relevan dengan karakteristik Kurikulum 2013 yang menetapkan capaian kompetensi peserta didik yang mencakup ketiga ranah pendidikan yaitu pengetahuan, keterampilan, dan sikap.

Guru merupakan pihak yang sangat berperan dalam proses pembelajaran. Oleh karena itu, guru benar-benar harus membimbing dan mengajar peserta didik pada pencapaian tujuan belajar yang sesungguhnya yang ingin direalisasikan. Seorang guru yang profesional harus bisa mempersiapkan dirinya dan menyiapkan rencana pelaksanaan pembelajaran yang baik agar kegiatan belajar mengajar yang efektif dan efisien dapat diwujudkan.

Salah satu tugas guru sebelum melaksanakan proses pembelajaran di kelas, terlebih dahulu guru mendesain dan menyiapkan perangkat pembelajaran. Perangkat pembelajaran yang harus dipersiapkan guru antara lain menyusun Rencana Pelaksanaan Pembelajaran (RPP) berdasarkan silabus yang telah ditetapkan. Rencana Pelaksanaan Pembelajaran (RPP) merupakan dokumen kegiatan pembelajaran yang menjadi acuan atau rambu-rambu dalam suatu kegiatan pembelajaran. RPP mencakup komponen; scenario pembelajaran, materi, strategi dan metode, dan sumber belajar yang akan digunakan dalam proses belajarmengajar. Pelaksanaan pembelajaran sangat terkait dengan rencana pembelajaran. Oleh sebab itu, pengkajian tentang pelaksanaan pembelajaran terlebih dahulu mengkaji tentang perencanaan pembelajaran yang didokumentasikan dalam Rencana Pelaksanaan Pembelajaran (RPP).

Seiring dengan pemberlakuan Kurikulum 2013 dalam pembelajaran PAI pada tingkat Sekolah Menengah Kejuruan (SMK) berimplikasi pada perubahan rencana pembelajaran termasuk komponen-komponen yang ada dalam Rencana Pelaksanaan Pembelajaran (RPP). Kecirian yang menonjol dari pemberlakuan Kurikulum 2013 adalah orientasi tujuan pembelajaran menitik beratkan pada kompetensi afektif peserta didik melalui aktivitas belajar, disamping kompetensi 
pengetahuan baik pengetahuan faktual maupun pengetahuan konseptual, dan kompetensi keterampilan.

Semua guru PAI yang ada di SMK Negeri 3 Parepare khususnya yang mengajar di kelas XI telah mengembangkan dan menyusun RPP sebelum melaksanakan prosers pembelajaran. Penyusunann RPP yang dibuat didasarkan pada Permendikbud Nomor 65 Tahun 2013 tentang Standar Proses yang menyatakan bahwa langkah awal dalam proses pembelajaran adalah perencanaan yang diwujudkan dengan kegiatan penyusunan Rencana Pelaksanaan Pembelajaran (RPP). Penyusunan RPP mereka lakukan secara tim melalui MGMP PAI .

Implementasi Kurikulum 2013 oleh guru PAI pada SMK Negeri 3 Parepare pertama-tama dapat dilihat dari Rencana Pelaksanaan Pembelajaran (RPP) yang disiapkan sebelum melaksanakan pembelajaran selain silabus yang telah ditetapkan pada tingkat nasional. RPP merupakan rencana pembelajaran yang dikembangkan secara rinci yang mengacu pada silabus, buku teks pelajaran, dan buku panduan guru. Berdasarkan hasil observasi di lapangan menunjukkan bahwa dokumen RPP yang dipersiapkan berdasarkan Permendikbud Nomor 65 Tahun 2013 yang diawali dengan mencantumkan identitas sekolah, mata pelajaran, kelas/semester, materi pokok, dan alokasi waktu. RPP memiliki 8 komponen utama, yakni: (1) Kompetensi Inti, (2) Kompetensi Dasar dan Indikator (3) Tujuan Pembelajaran, (4) Materi Pembelajaran, (5) Metode Pembelajaran, (6) Media, Alat, dan Sumber Pembelajaran, (7) Langkah-langkah Pembelajaran, dan (8) Penilaian.

Berdasarkan data yang diperoleh di lapangan dan hasil wawancara dengan 3 orang guru PAI yang mengajar di kelas XI, maka di peroleh data bahwa pengembangan RPP yang mereka susun merupakan rangkaian kegiatan yang dimulai dari kajian terhadap silabus dan buku guru/peserta didik dengan tujuan menyusun perencanaan kegiatan pembelajaran supaya efektif dan efisien, sehingga peserta didik dapat mencapai kompetensi yang telah ditentukan. Dengan demikian, maka pengembangan RPP dapat digambarkan sebagai suatu proses menjabarkan keterkaitan antara KI dan KD dengan ketercapaian SKL melalui proses pembelajaran dan penilaian.

Komponen tujuan pembelajaran pada RPP yang dipersiapkan oleh guru PAI kelas XI SMK Negeri 3 Parepare berdasarkan dokumen yang diperoleh di lapangan nampak variatif berdasarkan KD dan IPK yang ada.Pada perencanaan pertama untuk 2 kali pertemuan, tujuan pembelajaran disajikan ke dalam 5 tujuan pembelajaran. Pada perencanaan kedua untuk 2 kali pertemuan disajikan 7 tujuan pembelajaran. Pada perumusan tujuan pembelajaran disajikan secara utuh untuk masing-masing taksonomi tujuan pembelajaran, yakni pada aspek afektif, kognitif, dan psikomotorik. 
Perencanaan pembelajaran pada komponen pendekatan, model, dan metode menunjukkan ciri Kurikulum 2013, yaitu menggunakan pendekatan saintifik (pendekatan ilmiah) dengan model pembelajaran Inquiry Learning, Discovery Learning, Problem Based Learning, dan Project Based Learning. Adapun metode yang digunakan yaitu diskusi, tanya jawab, simulasi, demonstrasi, dan penugasan dan sudah disesuaikan dengan materi yang diajarkan.

Berdasarkan dokumen RPP yang diperoleh, pada komponen langkah-langkah pembelajaran guru masih menerapkan tiga tahapan (three steps) yakni pendahuluan, kegiatan inti, dan penutup. Tahapan pendahuluan, tercantum kegiatan persiapan sebelum pembelajaran inti dilaksanakan. Kegiatan ini meliputi memeriksa kesiapan peserta didik baik fisik maupun psikis, memberikan apersepsi dan motivasi, dan menyampaikan tujuan pembelajaran yang akan dicapai. Tahapan inti, mencantumkan langkah-langkah atau sintak dari model pembelajaran yang digunakan. Di dalam sintak tersebut nampaklah pendekatan saintifik yang meliputi kegiatan mengamati, menanya, mengumpulkan informasi, mengolah informasi, dan mengomunikasikan. Sedangkan pada tahapan penutup, tercantum kegiatan yang bersifat tindak lanjut, baik kesimpulan maupun tugas yang akan dikerjakan di rumah.

Langkah-langkah dalam perencanaan di atas menunjukkan bahwa pendekatan ilmiah yang menjadi ruh Kurikulum 2013 telah tergambar secara utuh. Hal ini telah menunjukkan adanya berbedaan dengan rancangan pembelajaran pada kurikulum sebelumnya baik KBK maupun KTSP. Gambaran ini membuktikan, bahwa pembelajaran PAI di kelas XI SMK Negeri 3 Parepare telah mengimplementasikan Kurikulum 2013.

Komponen terakhir dalam perencanaan pembelajaran adalah penilaian. Penilaian dimaksudkan untuk mengukur ketercapaian tujuan pembelajaran yang telah ditetapkan. Dalam konsep RPP bidang studi PAI di SMK Negeri 3 Parepare, menunjukkan bahwa penilaian pembelajaran juga mengembangkan instrument penilaian sikap, pengetahuan, dan keterampilan. Penilaian yang dilakaukan oleh guru PAI adalah dengan menggunakan penilaian autentik dan tes dsalam bentuk tertulis maupun lisan, pengamatan kinerja, pengukuran sikap, penggunaan portofolio, dan penilaian diri.

Berdasarkan paparan di atas menunjukkan, bahwa dari unsur perencanaan pembelajaran yang disiapkan oleh PAI kelas XI SMK Negeri 3 Parepare sebelum melaksanakan pembelajaran telah memenuhi kriteria Kurikulum 2013. Ciri utama Kurikulum 2013, yaitu dengan menggunakan pendekatan saintifik (ilmiah) dan penilaian autentik. Selanjutnya penulis akan memaparkan tentang pelaksanaan 
pembelajaran dan akan melihat apakah perencanaan yang telah dikembangkan dalam bentuk RPP diimplementasikan dalam pelaksanaan pembelajaran.

\section{Pelaksanaan Pembelajaran}

Pelaksanaan pembelajaran dalam Kurikulum 2013 yang dilakukan oleh guru PAI kelas XI SMK Negeri 3 Parepare, yaitu dengan menerapkan pendekatan saintifik (pendekatan ilmiah). Pendekatan ini berorientasi pada peserta didik atau menempatkan peserta didik sebagai subjek belajar, di mana mereka belajar dengan langkah-langkah ilmiah melalui pengamatan, bertanya, mengumpulkan informasi, mengolah informasi, dan selanjutnya mengomunikasikan atau mengembangkan jaringan informasi kepada pihak lain.

Hasil Pengamatan tentang Indikator Kegiatan Pendahuluan

\begin{tabular}{|c|l|c|c|c|c|}
\hline \multirow{2}{*}{ No. } & \multicolumn{1}{|c|}{ Aspek yang diamati } & \multicolumn{4}{c|}{ Jumlah Guru yang } \\
\cline { 3 - 6 } & & \multicolumn{1}{|c|}{ Melaksanakan (orang) } \\
\cline { 3 - 6 } & & 4 & 3 & 2 & 1 \\
\hline A. & $\begin{array}{l}\text { Apersepsi dan Motivasi } \\
\text { Mengaitkan materi pembelajaran sekarang } \\
\text { dengan pengalaman peserta didik atau } \\
\text { pembelajaran sebelumnya. }\end{array}$ & - & 2 & 1 & - \\
\hline 2. & Mengajukan pertanyaan menantang & & 1 & 2 & \\
\hline 3. & $\begin{array}{l}\text { Menyampaikan manfaat materi } \\
\text { pembelajaran }\end{array}$ & 1 & 2 & - & - \\
\hline 4. & $\begin{array}{l}\text { Mendemonstrasikan sesuatu yang terkait } \\
\text { dengan tema }\end{array}$ & - & 2 & 1 & - \\
\hline 5. & Mengecek perilaku awal (entry behavior) & 3 & - & - & - \\
\hline B. & $\begin{array}{l}\text { Menyampaikan Kompetensi dan Rencana } \\
\text { Kegiatan }\end{array}$ & & & & \\
\hline 6. & $\begin{array}{l}\text { Menyampaikan kemampuan yang akan } \\
\text { dicapai peserta didik }\end{array}$ & 1 & 2 & - & - \\
\hline 7. & Menyampaikan rencana kegiatan & - & 2 & 1 & \\
\hline
\end{tabular}

Sumber: Data Primer diolah, 2016

Berdasarkan Tabel di atas, hasil pengamatan pada pelaksanaan pembelajaran di SMK Negeri 3 Parepare yang melibatkan 3 (tiga) guru PAI yang mengajar di kelas XI menunjukkan bahwa pembelajaran diawali dengan tahap pendahuluan. Tahapan ini sesuai dengan perencanaan pembelajaran yang telah disiapkan. Kegiatan pendahuluan diawali dengan guru memberi salam kemudian menanyakan 
kehadiran peserta didik sambil memeriksa absensi peserta didik. Selanjutnya guru menanyakan kesehatan peserta didik dan kesiapannya untuk mengikuti kegiatan pembelajaran. Peserta didik menanggapi guru dengan menjawab secara serentak. Sebelum proses pembelajaran dilaksanakan, guru meminta salah satu peserta didik untuk memimpin doa bersama.

Pada kegiatan pendahuluan seperti yang nampak pada tabel tersebut menunjukkan bahwa ketiga guru PAI yang mengajar di kelas XI mengawali pembelajaran dengan melakukan apersepsi dan motivasi kepada peserta didik Pada kegiatan mengaitkan materi pembelajaran sekarang dengan pengalaman peserta didik atau pembelajaran sebelumnya, dari hasil pengamatan diperoleh data bahwa ada 2 guru yang menunjukkan nilai 3 yang berarti sudah melakukan dengan baik sesuai dengan perencanaan yang ada. Sedangkan 1 guru menunjukkan nilai 2 yang berarti masih kurang terlaksana dengan baik.

Selanjutnya pada kegiatan mengajukan pertanyaan menantang hanya 1 guru yang sudah melaksanakan dengan baik dan 2 guru kurang melaksanakan dengan baik. Pada kegiatan menyampaikan manfaat materi pembelajaran seorang guru menunjukkan angka 4 yang berarti telah melaksanakan dengan sangat baik, sementara 2 guru yang menunjukkan angka 3 yang berarti telah melaksanakan dengan baik.

Pada aspek mendemonstrasikan sesuatu yang terkait dengan tema, 2 guru telah melaksanakan dengan baik (nilai 3) dan seorang guru yang masih kurang dalam pelaksanaannya (nilai 2). Namun pada aspek mengecek perilaku awal (entry behavior) peserta didik, ketiga guru tersebut telah melaksanakan dengan sangat baik (nilai 4).

Selanjutnya pada komponen menyampaikan kompetensi dan rencana kegiatan, khususnya pada aspek menyampaikan kemampuan yang akan dicapai peserta didik menunjukkan bahwa hanya seorang guru yang telah melaksanakan dengan sangat baik (nilai 4) dan 2 orang guru sudah melaksanakan dengan baik (nilai 3). Hal terakhir yang dilakukan dalam kegiatan pendahuluan, yaitu menyampaikan rencana kegiatan. Dalam kegiatan ini menunjukkan 2 guru yang telah melaksanakan dengan baik (nilai 3) dan seorang guru masih kurang dalam pelaksanaannya (nilai 2), dalam hal ini guru tersebut tidak menyampaikan lebih dulu rencana kegiatan pembelajaran nantinya, apakah akan belajar secara berkelompok atau per individu sehingga peserta didik dapat mempersiapkan dirinya secara maksimal dalam proses pembelajaran nantinya.

Setelah kegiatan pendahuluan selesai, maka dilanjutkan dengan kegiatan inti dalam pembelajaran. Dari hasil pengamatan di lapangan, guru PAI di kelas XI SMK Negeri 3 Parepare pada kegiatan ini telah menunjukkan proses pembelajaran 
yang bercirikan Kurikulum 2013. Hal ini ditunjukkan dengan upaya guru untuk memberikan pengalaman belajar yang melibatkan proses mental dan fisik melalui interaksi antar peserta didik, peserta didik dengan guru, lingkungan, dan sumber belajar lainnya dengan menggunakan pendekatan saintifik atau pendekatan ilmiah.

Hasil Pengamatan tentang Indikator Kegiatan Inti pada Komponen Penguasaan Materi Pelajaran

\begin{tabular}{|c|l|c|c|c|c|}
\hline \multirow{2}{*}{ No. } & \multicolumn{1}{|c|}{ Aspek yang diamati } & \multicolumn{4}{|c|}{ Jumlah Guru yang } \\
& \multicolumn{1}{|c|}{\begin{tabular}{c} 
Melaksanakan (orang) \\
\cline { 2 - 6 }
\end{tabular}} & 4 & 3 & 2 & 1 \\
\hline 1. & $\begin{array}{l}\text { Kemampuan menyesuaikan materi dengan } \\
\text { tujuan Pembelajaran }\end{array}$ & - & 3 & - & - \\
\hline 2. & $\begin{array}{l}\text { Kemampuan mengaitkan materi dengan } \\
\text { pengetahuan lain yangrelevan, } \\
\text { perkembangan iptek, dan kehidupan nyata }\end{array}$ & & 2 & 1 & - \\
\hline 3. & $\begin{array}{l}\text { Mengelola pembahasan materi } \\
\text { pembelajaran dan pengalaman belajar } \\
\text { dengan tepat }\end{array}$ & - & 3 & - & - \\
\hline 4. & Menyajikan materi secara sistematis & - & 1 & 2 & - \\
\hline
\end{tabular}

Sumber: Data Primer diolah, 2016

Tabel di atas menunjukkan bahwa setelah melaksanakan tahap pendahuluan guru melanjutkan pada tahap inti pembelajaran. Pada tahap ini pengamatan berorientasi pada penguasaan materi pelajaran oleh guru PAI pada saat pembelajaran berlangsung. Dari hasil pengamatan menunjukkan bahwa, ketiga guru tersebut terpenuhi dan mampu menyesuaikan materi dengan tujuan pembelajaran dengan baik seperti yang tercantum pada rencana pembelajaran (nilai 3). Kemudian pada kemampuan mengaitkan materi dengan pengetahuan lain yang relevan, perkembangan iptek, dan kehidupaqn nyata terlihat 2 guru menunjukkan nilai 3 yang berarti telah terpenuhi, memahami, dan melaksanakan dengan baik, Sementara seorang guru masih kurang dalam pelaksanaannya (nilai 2).

Selanjutnya ketiga guru tersebut menunjukkan nilai 3 dalam kemampuan mengelola pembahasan materi pembelajaran dan pengalaman belajar dengan tepat dan telah melaksanakannya dengan baik. Pada kegiatan menyajikan materi secara sistematis, hanya seorang guru yang menunjukkan nilai 3 yang berarti telah melaksanakan dengan baik yaitu menayajikan materi dari yang mudah ke yang sulit dan dari yang konkret ke abstrak. Sedangkan 2 guru masih kurang dalam menyajikan materi secara sistematis (nilai2) dan terlihat dalam proses 
pembelajaran kedua guru tersebut lebih sering mengulang-ulang penjelasannya kepada peserta didik sehingga tidak tersistematis lagi materi pembelajarannya.

Hasil Pengamatan tentang Indikator Kegiatan Inti pada Komponen Penerapan

Strategi Pembelajaran yang Mendidik

\begin{tabular}{|c|c|c|c|c|c|}
\hline \multirow[t]{2}{*}{ No. } & \multirow[t]{2}{*}{ Aspek yang diamati } & \multicolumn{4}{|c|}{$\begin{array}{l}\text { Jumlah Guru yang } \\
\text { Melaksanakan (orang) }\end{array}$} \\
\hline & & 4 & 3 & 2 & 1 \\
\hline 1. & $\begin{array}{l}\text { Melaksanakan pembelajaran sesuai } \\
\text { dengan kompetensi yang akan dicapai }\end{array}$ & - & 3 & - & - \\
\hline 2. & $\begin{array}{l}\text { Memfasilitasi kegiatan yang memuat } \\
\text { komponen eksplorasi, elaborasi, dan } \\
\text { konfirmasi }\end{array}$ & - & 2 & 1 & - \\
\hline 3. & Melaksanakan pembelajaran secara teratur & - & 3 & - & - \\
\hline 4. & $\begin{array}{l}\text { Mengelola kelas (memelihara disiplin dan } \\
\text { suasana kelas) }\end{array}$ & 1 & 2 & - & - \\
\hline 5. & $\begin{array}{l}\text { Melaksanakan pembelajaran yang bersifat } \\
\text { kontekstual }\end{array}$ & - & 3 & - & - \\
\hline 6. & $\begin{array}{l}\text { Melaksanakan pembelajaran yang } \\
\text { memungkinkan tumbuhnya kebiasaan } \\
\text { positif/suasana kondusif }\end{array}$ & - & 3 & - & - \\
\hline 7. & $\begin{array}{l}\text { Melaksanakan pembelajaran sesuai } \\
\text { dengan alokasi waktu yang direncanakan }\end{array}$ & - & 2 & 1 & - \\
\hline
\end{tabular}

Sumber: Data Primer diolah, 2016

Tabel di atas menunjukkan bahwa pada komponen penerapan strategi pembelajaran yang mendidik nampak terlihat bahwa, pada aspek melaksanakan pembelajaran sesuai dengan kompetensi yang akan dicapai, aspek melaksanakan pembelajaran secara runtut, aspek melaksanakan pembelajaran yang bersifat kontekstual, dan aspek melaksanakan pembelajaran yang memungkinkan tumbuhnya kebiasaan positif atau suasana kondusif, ketiga guru tersebut telah melaksanakan dengan baik dalam proses pembelajaran (nilai 3). Hal ini terlihat pada antusiasme peserta didik dalam mengikuti proses pembelajaran dengan lebih mengaktifkan diri pada setiap kegiatan yang diberikan oleh guru. Sedangkan pada aspek memfasilitasi kegiatan yang memuat komponen eksplorasi, elaborasi, dan konfirmasi dan aspek melaksanakan pembelajaran sesuai dengan alokasi waktu yang direncanakan menunjukkan 2 guru telah melaksanakan dengan baik (nilai3), sementara seorang guru masih kurang dalam pelaksanaannya. Dari pengamatan 
pada aspek ini nampak guru tersebut tidak memperhitungkan waktu yang tersedia. Guru tidak mengatur dengan baik waktu yang harus digunakan dalam setiap langkah-langkah dalam pembelajaran, sehingga ada kegiatan yang menggunakan waktu yang cukup lama dan ada yang sangat sedikit.

Selanjutnya pada aspek mengelola kelas atau pengelolaan kelas seorang guru telah melaksanakan dengan sangat baik (nilai 4), karena guru tersebut telah mampu memelihara kedisiplinan dan menciptakan suasana kelas yang kondusif. Sedangkan 2 guru menunjukkan nilai 3 yang berarti guru tersebut telah melaksanakan dengan baik.

Hasil Pengamatan tentang Indikator Kegiatan Inti pada Komponen Penerapan Pendekatan Pembelajaran Saintifik (Pendekatan Berbasis Proses Keilmuan)

\begin{tabular}{|c|l|c|c|c|c|}
\hline \multirow{2}{*}{ No. } & \multicolumn{1}{|c|}{ Aspek yang diamati } & \multicolumn{3}{c|}{$\begin{array}{c}\text { Jumlah Guru yang } \\
\text { Melaksanakan (orang) }\end{array}$} \\
\cline { 3 - 6 } & & 4 & 3 & 2 & 1 \\
\hline 1. & Memfasilitasi peserta didik untuk mengamati & 3 & - & - & - \\
\hline 2. & Memancing peserta didik untuk menanya & - & 2 & 1 & - \\
\hline 3. & $\begin{array}{l}\text { Memberikan pertanyaan kepada peserta didik } \\
\text { untuk menalar (proses berpikir yang logis dan } \\
\text { sistematis }\end{array}$ & - & 3 & - & - \\
\hline 4. & Memfasilitasi peserta didik untuk mencoba & - & 3 & - & - \\
\hline 5. & $\begin{array}{l}\text { Menyajikan kegiatan peserta didik untuk } \\
\text { mengomunikasikan }\end{array}$ & 1 & 2 & - & - \\
\hline
\end{tabular}

Sumber: Data Primer diolah, 2016

Tabel di atas menunjukkan bahwa pada komponen penerapan pendekatan pembelajaran saintifik, guru PAI pada umumnya telah memahami dan menerapkannya dalam pembelajaran melalui kegiatan mengamati, menanya, mengumpulkan informasi, mengolah informasi, dan mengomunikasikan sesuai dengan karakteristik Kurikulum 2013. Hal ini terlihat pada data yang di peroleh di lapangan yang menunjukkan bahwa, pada aspek memfasilitasi peserta didik untuk mengamati ketiga guru tersebut telah melaksanakan dengan sangat baik (nilai 4). Hal ini ditandai dengan adanya objek berupa teks yang disediakan oleh guru untuk diamati.

Selanjutnya pada aspek memancing peserta didik untuk menanya terlihat bahwa 2 guru telah melaksanakan dengan baik (nilai 3) dan telah berhasil merangsang peserta didik untuk bertanya, sementara seorang guru masih kurang dalam pelaksanaannya (nilai 2), karena guru tersebut lebih banyak mengajukan 
pertanyaan kepada peserta didik. Pada aspek memberikan pertanyaan untuk menalar dan aspek memfasilitasi peserta didik untuk mencoba, ketiga guru tersebut telah melaksanakan dengan baik (nilai 3). Hal ini Nampak ketika guru banyak memberikan pertanyaan yang bertujuan untuk melatih peserta didik dalam proses berpikir yang logis dan sistematis. Pada aspek menyajikan kegiatan peserta didik untuk mengomunikasikan, seorang guru telah melaksanakan dengan sangat baik (nilai 4) karena semua kelompok dapat mempresentasekan hasil yang telah mereka kerjakan. Sementara itu 2 guru menunjukkan nilai 3 yang berarti telah melaksanakan dengan baik meskipun ada kelompok yang belum berkesempatan mempresentasekan tugasnya berhubung waktu pembelajaran telah selesai.

Dari hasil pengamatan pada saat kegiatan mengomunikasikan, guru telah memotivasi peserta didik untuk berani mengemukakan pendapatnya. Selain itu, guru juga membimbing peserta didik untuk menggunakan ajaran-ajaran yang yang tepat dan terstruktur. Pembelajaran bahasa harus melatih peserta didik untuk terampil dalam berbahasa. Aspek mengomunikasikan hasil pembelajaran merupakan bagian dari upaya mengaktifkan peserta didik dalam proses pembelajaran. Dengan mengomunikasikan hasil belajar kepada orang lain, pada prinsipnya peserta didik yang bersangkutan sedang melakukan aktivitas pembelajaran, baik untuk mempertegas pengetahuan yang dimiliki ataupun mengkonfirmasi pengetahuannya dengan orang lain. Oleh karena itu, mengomunikasikan hasil belajar merupakan komponen penting dalam pendekatan pembelajaran saintifik.

Hasil Pengamatan tentang Indikator Kegiatan Inti pada Komponen Pemanfaatan Sumber Belajar/Media dalam Pembelajaran

\begin{tabular}{|c|c|c|c|c|c|}
\hline \multirow[t]{2}{*}{ No. } & \multirow[t]{2}{*}{ Aspek yang diamati } & \multicolumn{4}{|c|}{$\begin{array}{c}\text { Jumlah Guru yang } \\
\text { Melaksanakan (orang) }\end{array}$} \\
\hline & & 4 & 3 & 2 & 1 \\
\hline 1. & $\begin{array}{l}\text { Menunjukkan keterampilan dalam penggunaan } \\
\text { sumber belajar pembelajaran }\end{array}$ & - & 2 & 1 & - \\
\hline 2. & $\begin{array}{l}\text { Menunjukkan keterampilan dalam penggunaan } \\
\text { media pembalajaran }\end{array}$ & - & 2 & 1 & - \\
\hline 3. & Menghasilkan pesan yang menarik & - & 3 & - & - \\
\hline 4. & $\begin{array}{l}\text { Melibatkan peserta didik dalam pemanfaatan } \\
\text { sumber belajar pembelajaran }\end{array}$ & - & 2 & 1 & - \\
\hline 5. & $\begin{array}{l}\text { Melibatkan peserta didik dalam pemanfaatan } \\
\text { media pembelajaran }\end{array}$ & - & 2 & 1 & - \\
\hline
\end{tabular}

Sumber: Data Primer diolah, 2016 
Tabel di atas menunjukkan, bahwa pada komponen pemanfaatan sumber belajar/media dalam pembelajaran tampak guru PAI yang mengajar di kelas XI belum semuanya dapat melaksanakan secara maksimal. Hal ini terlihat pada aspek menunjukkan keterampilan dalam penggunaan sumber belajar pembelajaran, aspek menunjukkan keterampilan dalam penggunaan media pembelajaran, aspek melibatkan peserta didik dalam pemanfaatan sumber belajar pembelajaran, dan melibatkan peserta didik dalam pemanfaatan media pembelajaran 2 guru menunjukkan nilai 3 yang berarti kedua guru tersebut telah melaksanakan dengan baik. Sementara itu seorang guru masih kurang dalam pelaksanaannya (nilai 2), sebab guru tersebut menggunakan sendiri dan hanya menjelaskan kepada peserta didik tanpa melibatkan mereka dalam pemanfaatan sumber dan media pembelajaran.

Sementara itu pada aspek menghasilkan pesan yang menarik, menunjukkan bahwa ketiga guru tersebut telah melaksanakan dengan baik (nilai 3). Hal ini terlihat pada saat peserta didik mampu mengaktifkan diri dalam pembelajaran, meskipun seorang guru masih kurang melibatkan peserta didik dalam pemanfaatan media dan sumber belajar, tapi guru tersebut mampu menjelaskan secara menarik materi yang diajarkan sehingga peserta didik antusias dalam pembelajaran.

Hasil Pengamatan tentang Indikator Kegiatan Inti pada Komponen Pelibatan Peserta Didik dalam Pembelajaran

\begin{tabular}{|c|l|c|c|c|c|}
\hline \multirow{2}{*}{ No. } & \multicolumn{1}{|c|}{ Aspek yang diamati } & \multicolumn{4}{|c|}{ Jumlah Guru yang } \\
\cline { 3 - 6 } & \multicolumn{1}{|c|}{\begin{tabular}{l}
\multicolumn{1}{|c|}{ Melaksanakan (orang) } \\
\cline { 3 - 6 }
\end{tabular}} & 4 & 3 & 2 & 1 \\
\hline 1. & $\begin{array}{l}\text { Menumbuhkan partisipasi aktif peserta } \\
\text { didik (mental, fisik, dan sosial) melalui } \\
\text { interaksi guru, pserta didik, sumber belajar }\end{array}$ & 1 & 2 & - & - \\
\hline 2. & Merespon positif partisipasi peserta didik & 1 & 2 & - & - \\
\hline 3. & $\begin{array}{l}\text { Menunjukkan sikap terbuka terhadap } \\
\text { respon peserta didik }\end{array}$ & - & 3 & - & - \\
\hline 4. & $\begin{array}{l}\text { Meunjukkan hubungan antar pribadi yang } \\
\text { kondusif }\end{array}$ & - & 3 & - & - \\
\hline 5. & $\begin{array}{l}\text { Menumbuhkan keceriaan atau antusiasme } \\
\text { peserta didik dalam belajar }\end{array}$ & - & 3 & - & - \\
\hline
\end{tabular}

Sumber: Data Primer diolah, 2016 
Data pada Tabel di atas menunjukkan bahwa ketiga guru tersebut secara umum telah melaksanakan semua aspek yang terdapat pada komponen pelibatan peserta didik dalam pembelajaran. Hal ini terlihat pada aspek menumbuhkan partisipasi aktif peserta didik dan aspek merespon positif partisipasi peserta didiki, seorang guru telah melaksanakan dengan sangat baik (nilai 4) dan 2 guru telah melaksanakan dengan baik (nilai 3). Dalam aspek ini ketiga guru telah berhasil menciptakan proses pembelajaran yang lebih banyak melibatkan peran peserta didik dalam membahas materi pelajaran. Hal ini sejalan dengan pernyataan Dra, $\mathrm{Hj}$. Nurmiah, selaku guru PAI yang mengajar di kelas XI yang diperoleh melalui wawancara pada tanggal 10 Oktober 2016 yang menyatakan bahwa:"Pada dasarnya Kurikulum 2013 ini sangat cocok untuk diterapkan dalam pembelajaran, khususnya bidang studi PAI. Pada kurikulum baru ini dapat melibatkatkan peserta didik secara aktif dengan pendekatan saintifiknya, Sebab, pada pembelajaran PAI kita bukan mengkhususkan pada pengetahuan berbahasa anak, tetapi pada keterampilan berbahasa mereka. Dengan pendekatan saintifik ini lebih berpusat kepada peserta didik bukan pada guru semata, keterlibatan peserta didik dengan porsi 70\% dan guru 30\% memungkinkan mereka dapat mengembangkan keterampilan berbahasanya dengan cara mencari tahu dan bukan diberitahu lagi dari guru”.

Berdasarkan pernyataan tersebut, menunjukkan bahwa guru PAI dapat menerima pemberlakuan Kurikulum 2013 di SMK Negeri 3 Parepare, dengan alasan pendekatan yang digunakan dalam kurikulum ini yang menjadi ciri khusus Kurikulum 2013 sangat cocok digunakan dalam pembelajaran. Selanjutnya pada aspek menunjukkan sikap terbuka terhadap respon peserta didik, aspek menunjukkan hubungan antar pribadi yang kondusif dan aspek menumbuhkan keceriaan atau antusiasme peserta didik dalam belajar, ketiga guru tersebut telah mampu melaksanakan dengan baik (nilai 3). Hal ini terlihat pada kemampuan ketiga guru tersebut dalam menciptakan suasana pembelajaran yang menyenangkan dan peserta didik tidak merasa tertekan sehingga mereka dapat daya pikir dan kreativitas mereka dalam pembelajaran.

Sebagai seorang guru, khususnya guru PAI dituntut mampu menggunakan bahasa Indonesia yang benar dan tepat dalam pembelajaran, Hal ini bertujuan agar komunikasi dalam pembelajaran khususnya pada saat mentransfer ilmu pengetahuan kepada peserta didik dapat berjalan dengan lancar sesuai dengan apa yang diharapkan tidak terkecuali bagi guru PAI yang mengajar di kelas XI SMK Negeri 3 Parepare. Berikut hasil pengamatan terhadap PAI pada komponen penggunaan bahasa yang benar dan tepat dalam pembelajaran.

Hasil Pengamatan tentang Indikator Kegiatan Inti pada Komponen Penggunaaan Bahasa yang Benar dan Tepat dalam Pembelajaran 


\begin{tabular}{|c|l|c|c|c|c|}
\hline \multirow{2}{*}{ No. } & \multicolumn{1}{|c|}{ Aspek yang diamati } & \multicolumn{4}{|c|}{ Jumlah Guru yang } \\
& \multicolumn{1}{|c|}{ Melaksanakan (orang) } \\
\cline { 3 - 6 } & \multicolumn{1}{|c|}{4} & 3 & 2 & 1 \\
\hline 1. & $\begin{array}{l}\text { Menggunakan bahasa lisan secara jelas dan } \\
\text { lancer }\end{array}$ & 3 & - & - & - \\
\hline 2. & $\begin{array}{l}\text { Menggunakan bahasa tulis yang baik dan } \\
\text { benar }\end{array}$ & 3 & - & - & - \\
\hline
\end{tabular}

Sumber: Data Primer diolah, 2016

Data Tabel di atas menunjukkan bahwa ketiga guru PAI telah melaksanakan dengan sangat baik (nilai 4) aspek menggunakan bahasa lisan secara jelas dan lancar dan aspek menggunakan bahasa tulis yang baik dan benar. Pada saat pengamatan berlangsung ketiga guru tersebut menunjukkan kemampuan yang sangat baik dalam berbahasa baik secara lisan maupun tertulis. Ini terlihat pada penguasaan kosa kata, penggunaan diksi, kejelasan artikulasi, dan terstrukturnya bahasa yang digunakan oleh ketiga guru tersebut, sehingga peserta didik dapat memahami dan mengerti apa yang diucapkan oleh guru.

Komponen terakhir dalam langkah-langkah pembelajaran seperti yang tercantum dalam rencana pembelajaran, yaitu kegiatan penutup pembelajaran. Dari hasil pengamatan di kelas, kegiatan penutup juga dilakukan oleh ketiga guru tersebut meskipun masih ada yang belum maksimal melaksanakannya. Berikut dipaparkan data yang diperoleh dari hasil pengamatan terhadap indikator kegiatan penutup pembelajaran yang dilakukan oleh guru PAI kelas XI.

Hasil Pengamatan tentang Indikator Kegiatan Penutup Pembelajaran

\begin{tabular}{|c|c|c|c|c|c|}
\hline \multirow[t]{2}{*}{ No. } & \multirow[t]{2}{*}{ Aspek yang diamati } & \multicolumn{4}{|c|}{$\begin{array}{l}\text { Jumlah Guru yang } \\
\text { Melaksanakan (orang) }\end{array}$} \\
\hline & & 4 & 3 & 2 & 1 \\
\hline 1. & $\begin{array}{l}\text { Melakukan refleksi atau membuat rangkuman } \\
\text { dengan melibatkan peserta didik }\end{array}$ & - & 2 & 1 & - \\
\hline 2. & Memberikan tes lisan atau tulisan & - & 3 & - & - \\
\hline 3. & $\begin{array}{l}\text { Mengumpulkan hasil kerja sebagai bahan } \\
\text { portofolio }\end{array}$ & - & 3 & - & - \\
\hline 4. & $\begin{array}{l}\text { Melaksanakan tindak lanjut dengan } \\
\text { memberikan arahan kegiatan berikutnya dan } \\
\text { tugas pengayaan }\end{array}$ & - & 3 & - & - \\
\hline
\end{tabular}

Sumber: Data Primer diolah, 2016 
Data pada Tabel di atas menunjukkan bahwa ketiga guru tersebut telah melaksanakan kegiatan penutup dengan baik (nilai 3), khususnya pada aspek memberikan tes lisan atau tulisan, aspek mengumpulkan hasil kerja sebagai bahan portofolio, dan aspek melaksanakan tindak lanjut dengan memberikan arahan kegiatan berikutnya dan tugas pengayaan. Sementara pada aspek melakukan refleksi atau membuat rangkuman dengan melibatkan peserta didik hanya 2 guru yang melaksanakan dengan baik (nilai 3) sedangkan seorang guru masih kurang dalam pelaksanaannya (nilai 2).

Data tersebut menunjukkan bahwa ketiga guru PAI telah melakukan pengumpulan hasil kerja peserta didik untuk dijadikan sebagai bahan portofolio. Hasil kerja yang dimaksud adalah lembar kerja secara kelompok yang berupa struktur dan cirri kebahasaan teks eksplanasi kompleks. Selanjutnya atas bimbingan guru, peserta didik membuat kesimpulan materi pembelajaran. Pada aspek ini, hanya 2 guru yang meminta peserta didik untuk membuat kesimpulan materi pembelajaran, sedangkan seorang guru masih membuat kesimpulan sendiri.

Meminta peserta didik untuk membuat kesimpulan pembelajaran lebih bermakna dari pada guru yang menyimpulkan sendiri, karena kesimpulan yang dibuat oleh peserta didik sekaligus dapat mengkonfirmasi penguasaan mereka terhadap materi yang telah dipelajari. Guru dalam hal ini berperan memperbaiki atau membenarkan jika ada hal-hal yang keliru dari kesimpulan yang dibangun oleh peserta didik. Konsep inilah yang menjadi karakteristik Kurikulum 2013. Dalam implementasi Kurikulum 2013, salah satu syarat yang harus dilakukan yaitu, melakukan penilaian autentik. Berikut ini penulis akan memaparkan tentang pelaksanaan penilaian autentik yang dilakukan oleh guru PAI kelas XI SMK Negeri 3 Parepare.

\section{Penilaian Pembelajaran}

Penilaian dalam proses pendidikan merupakan komponen yang tidak dapat dipisahkan dari komponen lainnya, khususnya pembelajaran. Penilaian dalam pembelajaran merupakan salah satu unsur yang mengalami perubahan dalam Kurikulum 2013. Penilaian merupakan proses pengumpulan dan pengolahan informasi untuk mengukur pencapaian hasil belajar peserta didik. Komponen penilaian pada Kurikulum 2013 mencakup 3 ranah untuk semua mata pelajaran, yaitu ranah afektif (sikap), kognitif (pengetahuan), dan psikomotorik (keterampilan).

Dalam implementasi Kurikulum 2013 mempersyaratkan penggunaan penilaian autentik. Secara paradigmatik penilaian autentik memerlukan perwujudan 
pembelajaran autentik. Hal ini dapat menunjukkan bahwa penilaian autentik lebih mampu memberikan informasi kemampuan peserta didik secara holistik dan valid.

Pelaksanaan Kurikulum 2013 di SMK Negeri 3 Parepare khususnya pada komponen penilaian, para guru tidak terkecuali guru PAI telah melakukan penilaian autentik dalam pembelajaran meskipun masih terdapat beberapa guru yang merasa kerepotan dengan model penilaian pada Kurikulum 2013.

Berdasarkan hasil wawancara menunjukkan bahwa guru, khususnya guru PAI pada dasarnya sangat setuju dengan adanya perubahan kurikulum. Kehadiran Kurikulum 2013 menurut mereka dapat menyempurnakan kurikulum-kurikulum sebelumnya, karena pendekatan saintifik yang merupakan salah satu karakteristik Kuurikulum 2013 mampu menciptakan proses pembelajaran yang kondusif, sehingga peserta didik dapat lebih aktif dan kreatif dalam belajar. Namun pada komponen penilaian, mereka merasa sangat kerepotan dan terlalu rumit dalam memberikan penilaian. Hal ini disebabkan karena, pada setiap pembelajaran mereka harus selalu mengisi rubrik penilaian yang bisa mengganggu konsentarasi mengajar mereka.

Berdasarkan dari data yang dikumpulkan melalui hasil wawancara dengan beberapa guru PAI yang ada di SMK Negeri 3 Parepare yang berjumlah 4 orang, menunjukkan bahwa masih ada guru yang belum membaca dan memahami pedoman penilaian yang digunakan sekarang ini. Hal ini menandakan bahwa kurangnya keseriusan guru tersebut untuk mencari informasi tentang pedoman penilaian yang berkaitan dengan mata pelajaran yang diampuhnya.

Hasil Pengamatan tentang Indikator Pelaksanaan Penilaian Pembelajaran yang Dilakukan oleh Guru pada Komponen Penilaian Penguasaan Pengetahuan

\begin{tabular}{|c|l|c|c|c|c|}
\hline \multirow{2}{*}{ No. } & \multicolumn{1}{|c|}{ Aspek yang diamati } & \multicolumn{4}{c|}{$\begin{array}{c}\text { Jumlah Guru yang } \\
\text { Melaksanakan (orang) }\end{array}$} \\
\cline { 3 - 7 } & \multicolumn{1}{|c|}{4} & 3 & 2 & 1 \\
\hline 1. & $\begin{array}{l}\text { Terlaksananya penilaian diakhir proses } \\
\text { pembelajaran, baik lisan maupun tulisan }\end{array}$ & 3 & - & - & - \\
\hline 2. & $\begin{array}{l}\text { Tersedianya dokumen hasil penilaian } \\
\text { penguasaan pengetahuan }\end{array}$ & 1 & 2 & - & - \\
\hline 3. & $\begin{array}{l}\text { Instrument penilaian yang digunakan } \\
\text { sesuai dengan kaidah }\end{array}$ & - & 3 & - & - \\
\hline 4. & $\begin{array}{l}\text { Momentum (waktu yang paling tepat) } \\
\text { melakukan penilaian }\end{array}$ & - & 3 & - & - \\
\hline
\end{tabular}

Sumber: Data Primer diolah, 2016 
Data pada Tabel di atas menunjukkan bahwa semua guru PAI yang mengajar di kelas XI telah melaksanakan penilaian diakhir proses pembelajaran, baik secara lisan maupun tulisan dengan sangat baik (nilai 4). Hal ini terlihat pada saat guru akan menutup pelajaran terlebih dahulu mengajukan beberapa pertanyaan kepada peserta didik dengan menyebut nama mereka dan rata-rata mereka mampu menjawab pertanyaan tersebut dengan baik. Setelah itu guru juga memberikan tes tulisan dalam bentuk kuis untuk mengukur sejauh mana pemahaman peserta didik dalam memahami materi pelajaran yang telah mereka peroleh.

Kemudian pada aspek tersedianya dokumen hasil penilaian penguasaan pengetahuan seorang guru telah melaksanakan dengan sangat baik (nilai 4) dan 2 guru juga sudah melaksanakan dengan baik (nilai 3). Hal ini terlihat pada daftar nilai yang dimiliki oleh guru, yang setiap akhir pembelajaran memberikan penilaian kepada peserta didik. Selanjutnya pada aspek instrumen penilaian yang digunakan sesuai dengan kaidah dan aspek momentum melakukan penilaian, ketiga guru tersebut telah melaksanakan dengan baik (nilai 3). Hal ini terlihat pada saat pembelajaran, guru menyediakan rubrik penilaian lengkap dengan criteria penilaian serta bobot penilaian, Instrumen penilaian ini juga tercantum pada Rencana Pelaksanaan Pembelajaran (RPP) yang telah disusun oleh guru sebelum proses pembelajaran dimulai. Guru tersebut juga telah menentukan waktu yang tepat untuk melaksanakan penilaian kepada peserta didik.

Hasil Pengamatan tentang Indikator Pelaksanaan Penilaian Pembelajaran yang

Dilakukan oleh Guru pada Komponen Penilaian Produk Pembelajaran.

\begin{tabular}{|c|c|c|c|c|c|}
\hline \multirow[t]{2}{*}{ No. } & \multirow{2}{*}{ Aspek yang diamati } & \multicolumn{4}{|c|}{$\begin{array}{c}\text { Jumlah Guru yang } \\
\text { Melaksanakan (orang) }\end{array}$} \\
\hline & & 4 & 3 & 2 & 1 \\
\hline 1. & $\begin{array}{l}\text { Tersedianya produk hasil pembelajaran } \\
\text { (model, project, pemecahan masalah) }\end{array}$ & - & 3 & - & - \\
\hline 2. & $\begin{array}{l}\text { Tersedianya himpunan hasil belajar } \\
\text { peserta didik lengkap dengan komentar } \\
\text { dan penilaian guru dalam satu portofolio }\end{array}$ & & 2 & 1 & - \\
\hline
\end{tabular}

Sumber: Data Primer diolah, 2016

Data pada Tabel 4.15. menunjukkan bahwa pelaksanaan penilaian pembelajaran yang dilakukan oleh guru, khususnya pada komponen penilaian produk pembelajaran ketiga guru PAI ini telah melasanakan dengan baik (nilai 3). Hal ini terlihat pada saat kegiatan inti dalam langkah-langkah pembelajaran telah terlaksana, nampak ketiga guru tersebut menyuruh peserta didik untuk membuat 
sebuah produk pembelajaran dalam hal ini peserta didik menentukan struktur teks eksplanasi kompleks dan memaknai teks tersebut. Sementara di kelas yang berbeda guru PAI yang lain menyuruh peserta didik untuk membandingkan dua teks eksplanasi, kemudian membuat produk hasil pembelajaran. Dalam hal ini peserta didik diminta untuk membuat teks eksplanasi kompleks dengan memilih salah satu tema dari 3 tema yang ditentukan oleh guru, yaitu tema lingkungan, sosial, dan pendidikan.Tugas ini dikerjakan dalam bentuk kelompok. Dalam proses mengerjakan tugas dari guru, nampak peserta didik saling berdiskusi dengan sesama anggota kelompoknya. Sementara itu terlihat guru memberikan penilaian proses terehadap peserta didik dengan mengisi rubrik penilaian yang telah disediakan sebelumnya.

Selanjutnya pada aspek tersedianya himpunan hasil belajar peserta didik lengkap dengan komentar dan penilaian guru dalam satu portofolio menunjukkan bahwa 2 guru telah melaksanakan dengan baik (nilai 3) dan seorang guru kurang melaksanakan aspek tersebut. Pada aspek ini 2 guru PAI sering mengumpulkan karya-karya atau hasil kerja peserta didik dalam bidang tertentu yang diorganisasikan untuk mengetahui minat, prestasi, perkembangan, dan kreativitas peserta didik dalam waktu tertentu. Sedangkan seorang guru, setelah memeriksa pekerjaan peserta didik langsung mengembalikan dan kurang mengumpulkan hasil karya atau tugas-tugas peserta didik untuk dijadikan portofolio, sehingga guru tersebut sulit untuk melihat perkembangan dan prestasi yang telah diperoleh peserta didik.

Berikut ini akan dipaparkan hasil pengamatan di lapangan tentang indikator pelaksanaan penilaian pembelajaran yang dilakukan oleh guru pada komponen penilaian iklim pembelajaran.

Hasil Pengamatan tentang Indikator Pelaksanaan Penilaian Pembelajaran yang

Dilakukan oleh Guru pada Komponen Penilaian Iklim Pembelajaran

\begin{tabular}{|c|l|c|c|c|c|}
\hline \multirow{2}{*}{ No. } & \multicolumn{1}{|c|}{ Aspek yang diamati } & \multicolumn{4}{|c|}{ Jumlah Guru yang } \\
& & \multicolumn{3}{|c|}{ Melaksanakan (orang) } \\
\cline { 3 - 6 } & & 4 & 3 & 2 & 1 \\
\hline 1. & $\begin{array}{l}\text { Terciptanya suasana atau aura } \\
\text { pembelajaran yang kondusif }\end{array}$ & - & 3 & - & - \\
\hline 2. & Terciptanya keteraturan suasana belajar & - & 3 & - & - \\
\hline
\end{tabular}

Sumber: Data Primer diolah, 2016 
Data pada Tabel di atas menunjukkan bahwa, semua guru PAI yang mengajar di kelas XI telah melaksanakan penilaian pembelajaran pada komponen penilaian iklim pembelajaran dengan baik (nilai 3) khususnya pada aspek terciptanya suasana atau aura pembelajaran yang kondusif dan terciptanya keteraturan suasana belajar. Hal ini sesuai dengan hasil pengamatan di kelas, di mana ketiga guru tersebut mampu menciptakan suasana pemelajaran yang menyenangkan dan tidak membosankan, sehingga peserta didik dapat mengikuti proses pembelajaran dengan baik dan penuh disiplin. Hal ini memudahkan guru untuk memberikan penilaian proses dan hasil belajar sesuai dengan ketentuan yang telah ditetapkan.

Berdasarkan pengamatan selama penelitian ini dilakukan, pada saat ketiga guru melaksanakan kegiatan penilaian, mulai dari penilaian proses yang menitikberatkan pada penilaian KI 1 dan KI 2 (sikap spiritual dan sikap sosial) sampai pada penilaian KI 3 dan KI 4 (pengetahuan dan keterampilan) nampak terlihat adanya penilaian proses dan penilaian hasil karya yang disertai dengan penggunaan teknik dan instrumen penilaian, misalnya format observasi atau rubrik penilaian. Berikut ini akan dipaparkan contoh format pengamatan/observasi sikap yang digunakan guru PAI kelas XI dalam pembelajaran.

Berdasarkan tuntutan Kurikulum 2013, penilaian pembelajaran tidak hanya dilakukan oleh guru semata tetapi peserta didik juga memberikan penilaian antar teman sejawat dan penilaian diri. Hal ini bertujuan untuk mengukur sejauh mana tingkat penguasaan materi yang telah dicapai oleh peserta didik dan materi apa yang belum dipahami. Berikut ini akan dipaparkan hasil pengamatan tentang indikator pelaksanaan penilaian pembelajaran pada komponen penilaian oleh peserta didik.

Hasil Pengamatan tentang Indikator Pelaksanaan Penilaian Pembelajaran pada Komponen Penilaian oleh Peserta Didik

\begin{tabular}{|c|l|c|c|c|c|}
\hline \multirow{2}{*}{ No. } & \multicolumn{1}{|c|}{ Aspek yang diamati } & \multicolumn{4}{|c|}{$\begin{array}{c}\text { Jumlah Guru yang } \\
\text { Melaksanakan (orang) }\end{array}$} \\
\cline { 3 - 6 } & \multicolumn{1}{|c|}{$\begin{array}{l}\mathbf{4} \\
\text { Nercapainya indikator perubahan } \\
\text { pengetahuan, sikap, dan keterampilan } \\
\text { peserta didik }\end{array}$} & - & 3 & - & - \\
\hline 2. & $\begin{array}{l}\text { Terekamnya kesan peserta didik terhadap } \\
\text { pembelajaran }\end{array}$ & - & 2 & 1 & - \\
\hline 3. & $\begin{array}{l}\text { Terekamnya semangat untuk belajar lebih } \\
\text { lanjut }\end{array}$ & - & 3 & - & - \\
\hline
\end{tabular}

Sumber: Data Primer diolah, 2016 
Data pada Tabel di atas menunjukkan bahwa, pada komponen penilaian oleh peserta didik tampak ketiga guru PAI pada umumnya telah melaksanakan dengan baik (Nilai 3), khususnya pada aspek yang bertujuan untuk mengetahui tercapainya indikator perubahan pengetahuan, sikap, dan keterampilan peserta didik dan aspek yang bertujuan merekam semangat untuk belajar lebih lanjut. Sementara pada aspek yang bertujuan untuk merekam kesan peserta didik terhadap pembelajaran hanya 2 guru yang melaksanakan dengan baik, sedangkan seorang guru masih kurang dalam pelaksanaannya (nilai 2). Guru tersebut hanya cenderung menggunakan instrumen atau format observasi yang khusus digunakan oleh guru untuk melihat perkembangan hasil belajar peserta didik dan kurang menggunakan penilaian yang dilakukan oleh peserta didik.

Dalam proses penilaian pembelajaran ada beberapa teknik yang dapat digunakan oleh pendidik. Untuk mengetahui teknik-teknik penilaian apa saja yang digunakan guru PAI kelas XI SMK Negeri 3 Parepare dalam melaksanakan penilaian, maka dilakukan wawancara kepada guru PAI yang bersangkutan. Hasil wawancara diperol;eh data yang menunjukkan bahwa ada beberapa teknik penilaian yang digunakan dalam proses penilaian pembelajaran, di antaranya adalah: (1) pengamatan/observasi (untuk aspek afektif), yang dilakukan untuk menilai proses pembelajara, (2) tes tertulis (untuk aspek kognitif) yang dilakukan untuk menilai hasil belajar, (3) tes praktik atau tes kinerja (untuk aspek psikomotor) yang dilakukan untuk menilai keterampilan berbahasa peserta didik, (4) penilaian penugasan, (5) penilaian jurnal, (6) penilaian portofolio, (7) penilaian diri, dan (8) penilaian antar teman.

\section{SIMPULAN}

Pada aspek perencanaan pembelajaran, guru SMK Negeri 3 Parepare khususnya guru pembelajaran PAI kelas XI terlebih dahulu mengembangkan dan menyusun Rencana Pelaksanaan Pembelajaran (RPP) berdasarkan silabus yang telah ditetapkan secara nasional. RPP yang disusun diawali dengan mencantumkan identitas sekolah, mata pelajaran, kelas/semester, materi pokok, dan alokasi waktu, kemudian dilanjutkan dengan mencantumkan 8 (delapan) komponen utama, yaitu; (a) kompetensi inti; (b) kompetensi dasar dan indikator; (c) tujuan pembelajaran; (d) materi pembelajaran; (e) pendekatan, model, dan metode pembelajaran; (f) media, alat, dan sumber pembelajaran; (g) langkah-langkah pembelajaran; dan (h) penilaian atau evaluasi.

Pada aspek pelaksanaan pembelajaran, guru SMK Negeri 3 Parepare khususnya guru bidang studi PAI yang mengajar di kelas XI secara umum telah menerapkan pendekatan saintifik (pendekatan ilmiah) dalam proses pembelajaran. 
Pendekatan saintifik sebagai ciri implementasi Kurikulum 2013, terdiri atas 5 langkah, yaitu; (a) mengamati; (b) menanya; (c) mengumpulkan informasi; (d) mengolah informasi; dan (e) mengomunikasikan.

Pada aspek penilaian pembelajaran, guru SMK Negeri 3 Parepare khususnya guru bidang studi PAI yang mengajar di kelas XI secara umum melakukan penilaian autentik dalam pembelajaran. Penilaian autentik sebagai cirri pelaksanaan Kurikulum 2013 dilakukan oleh guru PAI kelas XI dengan melakukan penilaian proses pembelajaran dan penilaian hasil belajar yang mencakup 3 ranah yaitu, ranah sikap, pengetahuan, dan keterampilan dengan menggunakan instrumen penilaian. Penilaian autentik yang terlaksana antara lain; (a) penilaian pengamatan atau observasi (proses); (b) penilaian pengetahuan berupa tes tertulis dan tes lisan; (c) penilaian diri; (d) penilaian antar teman; (e) penilaian jurnal; (f) penilaian kinerja; dan (g) penilaiana portofolio.

\section{DAFTAR PUSTAKA}

Abidin, Yunus. 2014. Desain Sistem Pembelajaran dalam Konteks Kurikulum 2013. Bandung: PT Refika Aditama.

Ahmad Tafsir, 1999. Ilmu Pendidikan Islam dalam Persfektif Pendidikan Islam (Ujung Pandang:Yayasan al-Ahkam.

Depdiknas. 2003. Undang-Undang Nomor 20 Tahun 2003 Tentang Sistem Pendidikan Nasional. Jakarta: Depdiknas.

Kardi, S., dan Nur Mohammad, 2011. Pengajaran Langsung. Surayabaya: University Press.

Kemendikbud, Permendikbud No. 81A Tahun 2013 tentang Implementasi Kurikulum 2013.

Kementerian Pendidikan dan Kebudayaan. 2014. Pedoman Implementasi Kurikulum 2013. Jakarta: Pusat Pengembangan Profesi Pendidik. Badan Pengembangan Sumber Daya Manusia Pendidikan dan Kebudayaan dan Penjaminan Mutu Pendidikan.

Kurniasih, Imas dan Berlin Sani, 2014. Implementasi Kurikulum 2013: Konsep dan Penerapan. Surabaya: Kata Pena.

Manab, Abdul. 2014. Manajemen Perubahan Kurikulum. Yogyakarta: Kalimedia.

Nana, S. 2008. Penilaian Hasil Proses Belajar Mengajar. Jakarta. PT Raja Grafindo Persada.

Rahman Getteng, 2007. Pendidikan Islam dan Pembangunan Ujung Pandang: Yayasan al-Ahkam. 
Trianto, 2013. “ Mempersiapkan Guru PAI dalam Mengimplementasikan Kurikulum.

Widyastono, Herry. 2014. Pengembangan Kurikulum di Era Otonomi Daerah. Jakarta: PT Bumi Aksara. 